\title{
Categorization of reliability of electrical appliances based on risk assessment
}

\author{
Michail Ershov ${ }^{1}$, Alexander Komkov ${ }^{1, *}$, and Irena Melik-Shaknazarova ${ }^{1}$ \\ ${ }^{1}$ National University of Oil and Gas «Gubkin University», Department of industrial electrical engineering, 199991 Moscow, Leninskiy \\ avenue, Russia
}

\begin{abstract}
The article proposes a methodology for assigning categories of power receivers according to the requirements of reliability of their power supply. The concept of "category of electrical receiver" is fundamental in relation to ensuring the reliability of power supply and has long been used in general industrial and industry guidance documentation. At the same time, the interpretation of long-formulated formulations regarding the attitude of the receiver to one or another category still remains ambiguous and allows for misunderstandings, which is especially evident in industry documents. In order to formalize the process of assigning a receiver to one or another category, to make it more objective, a technique is proposed that is based on recently actively developed methods of expert risk assessment. The methodology allows, without going over to monetary terms, to qualitatively assess risks and formalize the procedure for establishing the category of a particular electrical receiver. An example of an expert qualitative assessment of risks and the choice of a category of electric drive of a sucker-rod pump installation is given.
\end{abstract}

\section{Categorization of electrical appliances}

The main document defining the requirements for the reliability of the power supply of electric energy receivers - electric receivers (ER) are the Electrical Installation Rules (EIR) [1] approved by the Ministry of Energy of the Russian Federation (Order of July 8, 2002, No. 204). ER categories and requirements for ensuring the reliability of their power supply are established in Chapter 1.2, paragraphs 1.2.17-1.2.21. According to the EIR, in relation to ensuring the reliability of power supply, electric power divides into three categories.

The concept of "category of an electric receiver by the reliability of power supply" should not be attributed to the consumer as a whole, this concept is only valid in relation to an individual ER [2]. For the consumer, only a combination in various proportions of power receivers of categories I, II and III is characteristic.

Along with general industrial ones, there are industry regulatory documents for categorizing the reliability of power supply to energy receivers $[3,4]$. For industry documents, a characteristic is the desire to raise the requirements for the reliability of power supply to the power receiver, which is often due to the neglect of the availability of a technological reserve, the desire to establish unambiguous requirements regardless of the performance of the technological installation. Although the EIR, section 1.2.19 reads: "If it is impossible to ensure the continuity of the technological process by redundant power supply or if the redundant power supply is not economically feasible, technological redundancy should be carried out, for example, by installing mutually redundant technological units, special devices for emergency shutdown of technological production, operating in case of violation.

Power consumers, the disconnection of which leads to a massive shortage of products, is often referred not to category II, but to category I, motivating this decision by causing "significant damage to the national economy." The ambiguity of the wording of Ch. 1.2 EIR cannot be the basis for the transfer of ER of large-scale production from II to category I. The concept of "significant damage to the national economy" should be attributed to the group of industries (enterprises), region, industry, but not to one enterprise [2].

\subsection{Allowable power outage}

When establishing the reliability category of power supply, in addition to the requirements listed in the EIR, it is advisable to take into account such an important factor as the allowable time for a break in power supply. The duration of an allowable interruption in power supply should be justified and take into account the inertia of the provided technological process.

It is proposed that the power consumers according to the requirements for the allowable power supply time be differentiated into groups:

1. preventing rupture of sine wave supply voltage;

2. allowing a short break in power supply, determined by the inertia of electromechanical processes - tenths of a second;

* Corresponding author: komkov.a@gubkin.ru 
3. Allowing a short break in power supply, determined by the inertia of technological processes (flows) seconds;

4. Allowing a short interruption in power supply, determined by the inertia of the process equipment (the presence of energy / product storage) - tens of minutes;

5. Allowing a long break in the power supply, which can lead to a decrease in the productivity of the process more than 1 hour;

6. Allows an unlimited interruption in power supply, without affecting the process and safety.

From the above, we can conclude the need for a more flexible approach to categorizing the reliability of power consumers.

\subsection{Risk classification}

A solution to the problem of ensuring the required level of reliability of energy supply could be facilitated by a system of insurance of risks from interruptions in energy supply. To create it requires the study of legal, financial and technical issues. The technical issues include the creation of a methodological base for assessing the risks of power outages. To create it requires the study of legal, financial and technical issues. The technical issues include the creation of a methodological base for assessing the risks of power outages. Methods for assessing risks in production activities are increasingly used in industry [5].

Risk identification is carried out by various methods $[5,6,7,8,9]$. In this paper, for risk assessment, the method of "analysis of the consequences of risk" is adopted taking into account the method of "analysis of risk factors" [5]. These methods most fully meet the objectives of power supply systems and allow you to take into account features - factors that determine the requirements for the reliability of power supply to power consumers.

The classification of risks by consequences is carried out in accordance with the provisions of the EIR [1], paragraph 1.2.17-1.2.21:

1. State risk:

1.1. Threat to state security;

1.2. Significant material damage;

1.3. Violation of the functioning of particularly important elements of public utilities, communication facilities;

2. Personnel risk:

2.1. Danger to human life;

2.2. Violations of normal activities of a significant number of employees or residents;

3. Property risk:

3.1. Decrease in the value of tangible assets as a result of equipment failure or reduction of its resource and other direct losses;

4. Production and economic risk:

4.1. Upset of a complex process;

4.2. Massive undersupply of products (non-fulfillment of the plan for production, processing, transportation, sales, non-receipt of planned income), lost profit;

5. Environmental risk:
5.1. Violations of regulatory values of maximum permissible concentrations of emissions and environmental pollution.

The classification of risks by factors is carried out taking into account the provisions of the EIR [1], paragraph 1.2.19 and is presented below:

1. Internal risk

1.1. Technological;

1.1.1.The presence of technological reserve;

1.1.2. The value of the allowable break time in the power supply;

1.2. Technical

1.2.1.Availability of technological and electrical automatic control systems operating in emergency conditions.

\section{Power failure risk assessment}

Risk assessments are carried out at a qualitative or quantitative level. Quantitative risk assessment is used when it is possible to determine the consequences of a risk event in cash. An approach based on a quantitative risk assessment requires the development of additional techniques, including a damage assessment methodology, and this approach is not used in this work.

\subsection{Qualitative risk assessment}

To determine a qualitative risk assessment, it is necessary to assess the most anticipated possible consequences of the risk realization indicated above in the risk classifier by consequences. The probability of risk is assessed taking into account the factors listed above.

At the first stage, the category of the electrical receiver is determined by its importance within the technological chain, as well as by its role in ensuring the safety of the facility.

To determine a qualitative risk assessment, it is necessary to assess the most anticipated possible consequences of the risk implementation indicated above in the risk classifier. An example of a scale for a qualitative assessment of the magnitude of the consequences of risk is presented in table 1. Risk probabilities are evaluated on the scale presented in table 2 . The probability of risks is assessed taking into account the factors listed above, the assessment of which is carried out on the scale of assessment of factors, an example of which is presented in table 3 .

The risk assessment of power supply failure of the energy receiver is recommended to be carried out expertly. Table 4 presents the form of the questionnaire, filled out by experts - specialists in the relevant fields of technology and electric power.

\subsection{Calculation of the assessment of the magnitude of the consequences}

Based on the survey results, the calculation of the magnitude of the consequences of risk (MCR) and the 
probability of risk (PR) is carried out according to the relevant formulas

$$
\begin{gathered}
M C R_{k}=\sum\left(M C R_{k i} / N\right) \text { for } i=1 \text { to } N ; \\
P R_{k}=\sum\left(k_{k i} P R_{k i} / N\right) \text { for } i=1 \text { to } N,
\end{gathered}
$$

where $M C R_{k i}$ and $P R_{k i}$ - the magnitude of the consequences of the $k$-th risk and the probability value of the $k$-th risk, according to the $i$-th expert; $N$ - number of experts; $k_{k i}$ - correction factor; $k$ - risk number.

To assess the probabilities of state risks and the risks of impact on personnel, the value of correction factors is taken equal to unity

$$
k_{1 i}=k_{2 i}=1 \text {. }
$$

\begin{tabular}{|c|c|c|c|}
\hline \multirow[b]{3}{*}{$\begin{array}{l}\text { Magnitu } \\
\text { de of the } \\
\text { effects of } \\
\text { risk }\end{array}$} & \multicolumn{3}{|c|}{ Criteria for evaluation } \\
\hline & \multirow{2}{*}{$\begin{array}{c}\begin{array}{c}\text { 1. State } \\
\text { risk }\end{array} \\
\\
\text { Any } \\
\text { conseque } \\
\text { nces of } \\
\text { state risk }\end{array}$} & \multicolumn{2}{|c|}{ 2. Personnel risk } \\
\hline & & $\begin{array}{l}\text { Danger to } \\
\text { human life }\end{array}$ & $\begin{array}{l}\text { Disruptions to } \\
\text { the normal } \\
\text { activities of a } \\
\text { significant } \\
\text { number of } \\
\text { employees or } \\
\text { residents } \\
\end{array}$ \\
\hline $\begin{array}{c}\text { Insig- } \\
\text { nificant } \\
\text { (1 point) }\end{array}$ & - & Microtrauma & - \\
\hline $\begin{array}{l}\text { Permis- } \\
\text { sible } \\
\text { (2 points) }\end{array}$ & - & Minor injuries & $\begin{array}{l}\text { Disruptions to the } \\
\text { normal activities } \\
\text { of a group }(>10) \\
\text { workers or } \\
\text { residents for a } \\
\text { period from } 12 \\
\text { hours to a day }\end{array}$ \\
\hline $\begin{array}{l}\text { Signifi- } \\
\text { cant } \\
\text { (3 points) }\end{array}$ & - & $\begin{array}{c}\text { Moderate } \\
\text { harm to health }\end{array}$ & $\begin{array}{l}\text { Disruptions to the } \\
\text { normal activities } \\
\text { of a group }(>10) \\
\text { workers or } \\
\text { residents for a } \\
\text { period from one } \\
\text { day to } 7 \text { days }\end{array}$ \\
\hline $\begin{array}{l}\text { Critical } \\
\text { (4 points) }\end{array}$ & $\begin{array}{l}\text { Establishe } \\
\mathrm{d} \text { by the } \\
\text { requireme } \\
\text { nt of the } \\
\text { state } \\
\text { authorities } \\
\text { of the } \\
\text { region }\end{array}$ & $\begin{array}{l}\text { Group causing } \\
\text { harm to health } \\
\text { of moderate } \\
\text { severity, } \\
\text { occupational } \\
\text { diseases } \\
\text { (poisoning). } \\
\text { Solitary fatal } \\
\text { accidents }\end{array}$ & $\begin{array}{l}\text { Disruptions to the } \\
\text { normal activities } \\
\text { of a group }(>10) \\
\text { workers or } \\
\text { residents for a } \\
\text { long time, } \\
\text { associated with the } \\
\text { need to evacuate } \\
\text { people }\end{array}$ \\
\hline $\begin{array}{c}\text { Catastro- } \\
\text { phic } \\
\text { (5 points) }\end{array}$ & $\begin{array}{l}\text { Establishe } \\
\mathrm{d} \text { by the } \\
\text { requireme } \\
\mathrm{nt} \text { of the } \\
\text { state } \\
\text { authorities } \\
\text { of the } \\
\text { region }\end{array}$ & $\begin{array}{l}\text { Group fatal } \\
\text { accidents, } \\
\text { serious } \\
\text { occupational } \\
\text { diseases } \\
\text { (poisoning), } \\
\text { including the } \\
\text { population of } \\
\text { the territories }\end{array}$ & $\begin{array}{c}\text { Violations of the } \\
\text { normal activities } \\
\text { of all employees } \\
\text { or all residents of } \\
\text { settlements for a } \\
\text { long time, } \\
\text { associated with the } \\
\text { need to evacuate } \\
\text { people }\end{array}$ \\
\hline
\end{tabular}

Table 1. An example of a scale for a qualitative assessment of the magnitude of the consequences of risk.

\begin{tabular}{|c|c|c|c|}
\hline $\begin{array}{l}\text { Qualitative } \\
\text { assessment } \\
\text { of } \\
\text { probability }\end{array}$ & $\begin{array}{c}\text { Probability } \\
\text { characteristic }\end{array}$ & $\begin{array}{l}\text { Quantif } \\
\text { ying the } \\
\text { probabil } \\
\text { ity value }\end{array}$ & $\begin{array}{c}\text { Quantifying } \\
\text { the range of } \\
\text { probability }\end{array}$ \\
\hline $\begin{array}{l}\text { Very low } \\
\text { (1 point) }\end{array}$ & $\begin{array}{l}\text { Rare event, may } \\
\text { occur in } \\
\text { exceptional cases }\end{array}$ & 0.10 & $0-0.15$ \\
\hline $\begin{array}{c}\text { Low } \\
\text { (2 point) }\end{array}$ & $\begin{array}{c}\text { The risk event } \\
\text { may occur within } \\
4 \text { years }\end{array}$ & 0.25 & $>0.15-0.40$ \\
\hline $\begin{array}{l}\text { Average } \\
\text { (3 point) }\end{array}$ & $\begin{array}{l}\text { The risk event } \\
\text { may occur within } \\
2 \text { years }\end{array}$ & 0.50 & $>0.40-0.60$ \\
\hline $\begin{array}{c}\text { High } \\
\text { (4 point) }\end{array}$ & $\begin{array}{l}\text { The risk event can } \\
\text { occur within } 1 \\
\text { year }\end{array}$ & 0.75 & $>0.60-0.85$ \\
\hline $\begin{array}{l}\text { Very high } \\
\text { (5 point) }\end{array}$ & $\begin{array}{l}\text { Risk event. Most } \\
\text { likely to happen } \\
\text { within } 1 \text { year, } \\
\text { there is statistics } \\
\text { of multiple } \\
\text { occurrence of the } \\
\text { event within } 1 \\
\text { year in the past }\end{array}$ & 0.90 & $>0.85-1.0$ \\
\hline
\end{tabular}

Table 2. Risk probability assessment scale.

Note -- the probability of an impossible event is zero

The values of the correction factors for property $k_{3 i}$, production and economic $k_{4 i}$ and environmental $k_{5 i}$ risks are taken equal and are determined based on the results of the assessment of internal (technological and technical) factors $(F)$ according to the scale presented in table 3. External technical factors from table 3 are recommended to be considered at reconstruction of power supply systems. If the sum of the assessments of factors made by the $i$-th expert is from 3 to 7 , then the value of the coefficients for this expert is taken equal to 0.75 , if the sum of the assessments of factors is not less than 8 , then the value of the coefficient is taken to be 0.5 , otherwise the value of the coefficient is taken equal to 1.0 .

$$
\begin{gathered}
k_{3 i}=k_{4 i}=k_{5 i}=0.5, \text { if } F \geq 8 ; \\
k_{3 i}=k_{4 i}=k_{5 i}=0.75, \text { if } 8>F \geq 3 ; \\
k_{3 i}=k_{4 i}=k_{5 i}=1.0, \text { if } F<3 .
\end{gathered}
$$

Qualitative Integrated Assessment (QIA) contains a point assessment of possible damage resulting from the implementation of a risk event, taking into account the probability of its occurrence, and is determined by the formula

$$
Q I A=\sum\left(M C R_{k} \cdot P R_{k}\right), \text { for } k=1 \text { to } 5 .
$$

The basis for establishing the category of the electric receiver according to the requirements for reliability of power supply should be the fulfillment of the conditions listed in table 4.

When determining the category, additional conditions for the following risks are taken into account: 
- $\quad$ Any consequences of the state risk (1.1-1.3) - if the assessment of the magnitude of the consequences is 4 or 5 , then the electric receiver belongs to category 1 , regardless of the assessments of other risks;

- Danger to human life (2.1) - if the assessment of the magnitude of the consequences is 3 or more, then the electrical receiver belongs to category 1 regardless of the assessments of the remaining risks;

- Danger to human life (2.1) - if the magnitude of the consequences is 4 or 5 , then the electrical receiver belongs to the "special group" of the 1st category, regardless of the ratings other risks.

Table 3. An example of a scale for a qualitative assessment of the influence of related factors on the requirements for the reliability of power supply of an electric drive.

\begin{tabular}{|c|c|c|}
\hline \multirow{3}{*}{$\begin{array}{l}\text { Characteri } \\
\text { zation and } \\
\text { assessment } \\
\text { of the } \\
\text { influence } \\
\text { of the } \\
\text { factor }\end{array}$} & \multicolumn{2}{|c|}{ Factor } \\
\hline & \multicolumn{2}{|c|}{ 1.1. Internal technological } \\
\hline & $\begin{array}{c}\text { 1.1.1. The presence } \\
\text { of technological } \\
\text { reserve }\end{array}$ & $\begin{array}{l}\text { 1.1.2. The value of } \\
\text { the allowable } \\
\text { break time in the } \\
\text { power supply }\end{array}$ \\
\hline $\begin{array}{l}\text { Insig- } \\
\text { nificant } \\
\text { (1 point) }\end{array}$ & $\begin{array}{l}\text { The presence of } \\
\text { duplicate equipment } \\
\text { in an unloaded } \\
\text { reserve, the } \\
\text { introduction of which } \\
\text { into operation is } \\
\text { accompanied by a } \\
\text { long (more than } 1 \\
\text { hour) disruption of the } \\
\text { technological process }\end{array}$ & $\begin{array}{c}\text { Allowing a short } \\
\text { interruption in the } \\
\text { power supply, } \\
\text { determined by the } \\
\text { inertia of } \\
\text { technological streams } \\
\text { - up to several seconds }\end{array}$ \\
\hline $\begin{array}{c}\text { Permissible } \\
\text { (2 points) }\end{array}$ & $\begin{array}{l}\text { The presence of } \\
\text { duplicate equipment } \\
\text { in an unloaded } \\
\text { reserve, the } \\
\text { introduction of which } \\
\text { into operation is } \\
\text { accompanied by a } \\
\text { short-term (more than } \\
1 \text { hour) disruption of } \\
\text { the technological } \\
\text { process }\end{array}$ & $\begin{array}{l}\text { Allowing short-term } \\
\text { interruption in power } \\
\text { supply, determined by } \\
\text { the inertia of } \\
\text { technological } \\
\text { equipment } \\
\text { (availability of storage } \\
\text { devices) - up to } 1 \text { hour }\end{array}$ \\
\hline $\begin{array}{c}\text { Significant } \\
\text { (3 points) }\end{array}$ & $\begin{array}{c}\text { The presence of } \\
\text { duplicate equipment } \\
\text { in the loaded reserve, } \\
\text { for a short time (up to } \\
1 \text { hour) replacing the } \\
\text { failed }\end{array}$ & $\begin{array}{c}\text { Allows a long } \\
\text { interruption in the } \\
\text { power supply, which } \\
\text { can lead to a decrease } \\
\text { in the productivity of } \\
\text { the technological } \\
\text { process - more than } 1 \\
\text { hour }\end{array}$ \\
\hline $\begin{array}{c}\text { Critical } \\
\text { (4 points) }\end{array}$ & $\begin{array}{c}\text { The presence of } \\
\text { duplicate equipment } \\
\text { in the loaded reserve } \\
\text { for a long time (more } \\
\text { than } 1 \text { hour) replacing } \\
\text { the failed }\end{array}$ & $\begin{array}{c}\text { Allows a long } \\
\text { interruption in the } \\
\text { power supply, which } \\
\text { does not affect the } \\
\text { technological process } \\
\text { and safety - more than } \\
1 \text { hour }\end{array}$ \\
\hline $\begin{array}{l}\text { Catastro- } \\
\text { phic } \\
\text { (5 points) }\end{array}$ & $\begin{array}{c}\text { The presence of } \\
\text { duplicate equipment } \\
\text { in the loaded reserve, } \\
\text { indefinitely replacing } \\
\text { the failed one }\end{array}$ & $\begin{array}{l}\text { Allows unlimited } \\
\text { power interruption } \\
\text { without affecting } \\
\text { process and safety }\end{array}$ \\
\hline
\end{tabular}

Note - in the complete absence of the influence of the factor, its estimate is considered equal to zero.

Table 4. Correspondence between categories of power consumers and risks of power failure.

\begin{tabular}{|c|c|c|}
\hline \multirow{2}{*}{$\begin{array}{l}\text { Consumer } \\
\text { category }\end{array}$} & \multicolumn{2}{|c|}{ Risk categorization conditions } \\
\hline & $\begin{array}{c}\text { Qualitative } \\
\text { Integrated } \\
\text { Assessment (points) }\end{array}$ & $\begin{array}{l}\text { Number of critical } \\
\text { consequences }\end{array}$ \\
\hline $\begin{array}{c}\text { First } \\
\text { category }\end{array}$ & over 24 & $\begin{array}{c}\text { At least two critical or } \\
\text { one catastrophic } \\
\text { consequences }\end{array}$ \\
\hline $\begin{array}{l}\text { Second } \\
\text { category }\end{array}$ & over 14 to 24 & $\begin{array}{l}\text { At least one critical } \\
\text { consequence }\end{array}$ \\
\hline $\begin{array}{l}\text { Third } \\
\text { category }\end{array}$ & up to 14 & $\begin{array}{c}\text { Lack of critical and } \\
\text { catastrophic } \\
\text { consequences }\end{array}$ \\
\hline
\end{tabular}

\section{An example of determining the reliability category of an electrical receiver}

An example of a questionnaire for determining the category of power supply reliability of an electric drive of a sucker rod pumping unit (SRPU) is shown in Table 5. The values of the correction factors are selected according to conditions (4), (5) and (6) after evaluating the factors presented in table 3 .

The object is an electric drive of a sucker rod pumping unit SKN5-3015 of an oil production well, an asynchronous motor $P_{\text {nom }}=15 \mathrm{~kW}$.

Let's conduct a qualitative assessment of the influence of related factors. Since there is no duplicate equipment, the assessment of the influence of the factor "1.1.1. The presence of a technological reserve" is equal to 0 . According to the condition of admissibility of a long power outage of more than 1 hour, which can lead to a decrease in the productivity of the technological process, according to the factor "1.1.2 The value of the allowable power outage time", score 3 is selected. The restoration of the technological process is provided due to the automatic restart of the electric receiver, therefore, the assessment of the influence of the factor "1.2.1 Availability of technological and electrical automatic control systems operating in post-emergency modes" is equal to 2. Having determined the total value of the estimates of the named factors, we obtain $F=5$. According to condition (5), the values of the correction factors are $k_{3 \mathrm{i}}=k_{4 \mathrm{i}}=k_{5 \mathrm{i}}=0.75$.

The qualitative integral risk assessment determined by formulas (7), (1) and (2) is QIA = $0 \cdot(1 \cdot 0)+0 \cdot(1 \cdot 0)+0 \cdot(1 \cdot 0)+1 \cdot(0.75 \cdot 1)+1 \cdot(0.75 \cdot 4)+1 \cdot(0.75 \cdot 2)$ $+0 \cdot(0.75 \cdot 0)=5.25$. According to the criteria presented in table 4, (QIA <14, there are no critical and catastrophic consequences)), the electric receiver is assigned the $3 \mathrm{rd}$ category of power supply reliability. 
Table 5. An expert survey questionnaire for a qualitative risk assessment in order to determine the category of an electric consumer - an electric drive of the SRPU.

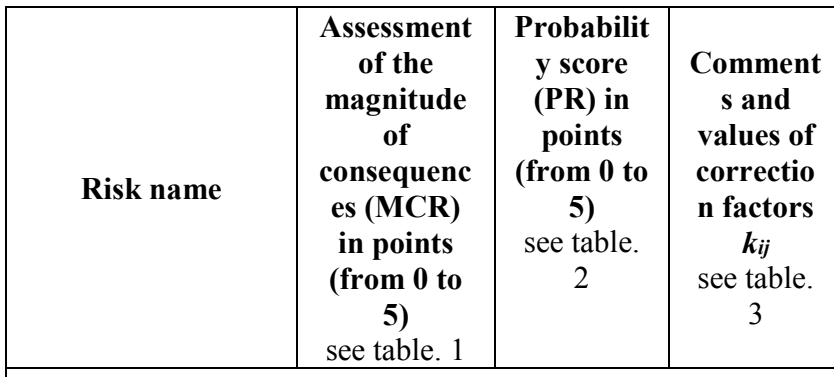

\section{State risk}

\begin{tabular}{|c|c|c|c|}
\hline $\begin{array}{c}\text { 1.1.-1.3. Any } \\
\text { consequences of } \\
\text { state risk }\end{array}$ & 0 & 0 & 1 \\
\hline
\end{tabular}

\begin{tabular}{|c|c|c|c|}
\hline \multicolumn{2}{|c|}{ 2. Personnel risk } \\
\hline $\begin{array}{c}\text { 2.1. Danger to } \\
\text { human life }\end{array}$ & 0 & 0 & 1 \\
\hline $\begin{array}{c}\text { 2.2. Violations } \\
\text { of normal } \\
\text { activities of a } \\
\text { significant } \\
\text { number of } \\
\text { Company } \\
\text { employees } \\
\text { (massive } \\
\text { downtime of } \\
\text { workers) or } \\
\text { residents }\end{array}$ & 0 & 0 & \\
\hline
\end{tabular}

\begin{tabular}{|c|c|c|c|}
\hline \multicolumn{3}{|c|}{ 3. Property risk } \\
\hline $\begin{array}{c}\text { 3.1. Decrease in } \\
\text { the value of } \\
\text { tangible assets as } \\
\text { a result of } \\
\text { equipment } \\
\text { failure or } \\
\text { reduction of its } \\
\text { resource }\end{array}$ & 1 & 1 & \begin{tabular}{c} 
\\
$F=5$ \\
\hline
\end{tabular} \\
\hline
\end{tabular}

4. Production and economic risk

\begin{tabular}{|c|c|c|c|}
\hline $\begin{array}{l}\text { 4.1. Upset of a } \\
\text { complex process }\end{array}$ & 1 & 4 & $\begin{array}{c}0,75 \\
F=5\end{array}$ \\
\hline $\begin{array}{l}\text { 4.2. Massive } \\
\text { undersupply of } \\
\text { products (non- } \\
\text { fulfillment of the } \\
\text { plan for } \\
\text { production, } \\
\text { processing, } \\
\text { transportation, } \\
\text { sales, non- } \\
\text { receipt of } \\
\text { planned } \\
\text { income), lost } \\
\text { profit }\end{array}$ & 1 & 2 & $\begin{array}{c}0,75 \\
F=5\end{array}$ \\
\hline
\end{tabular}

\section{Environmental risk}

\begin{tabular}{|c|c|c|c|}
\hline $\begin{array}{c}\text { 5.1. Violations } \\
\text { of regulatory } \\
\text { values of }\end{array}$ & & & \\
$\begin{array}{c}\text { maximum } \\
\text { permissible } \\
\text { concentrations } \\
\text { of emissions and } \\
\text { environmental } \\
\text { pollution }\end{array}$ & 0 & 0 & 0,75 \\
\hline
\end{tabular}

\section{Conclusion}

A new approach to determining the indicators of the reliability of power supply of industrial power consumers, based on industry standards for risk assessment, is considered. This approach allows you to determine the category of an individual electrical consumer using a qualitative assessment. This allows enterprises to more consciously spend funds on providing the category of electrical consumers. This excludes the provision of an overstated category of power supply for electrical consumers.

\section{References}

1. Electrical installation rules, seventh edition (approved by order of the Ministry of Energy of the Russian Federation dated July 8, 2002 No. 204)

2. NTP EPP-94. Technological design standards. Design of power supply for industrial enterprises (instead of SN-174-75). Moscow: OAO «Tyazhprome'lektroprekt» imeni F.B. Yakubovskogo. 1994.

3. STO Gazprom 2-6.2-149-2007 Category of electrical receivers of industrial facilities of JSC Gazprom. 2007.

4. VNTP 3-85 Ministry of Oil Industry. Norms of technological design of objects of gathering, transport, preparation of oil, gas and water of oil field. Moscow: 1985.

5. I.I. Ryzhkin, "Technical risks insurance”, Moscow: Alfa-Press Publishing House. 2010.

6. G. Vedotova, N.I. Voropaj, Optimization of the reliability of power supply to consumers, "Reliability: Theory\& Applications", no. 2. pp. 126139. 2007.

7. I.V. Belousenko, M.D. Dilman, L.S. Popyrin, "Energy security of the Unified Gas Supply System of Russia”, Moscow: Nauka publishing house. 2006.

8. R. Billinton and R. Allan, "Reliability Evaluation of Power Systems”. New York: Plenum Press, 1996.

9. M. Rausand and A. Hoyland, "System Reliability Theory. Models, Statistical Methods and Applications", 2nd Edition. Hoboken, N.J.: John Wiley and Sons, 2004. 